Special Issue 特集論文

Invited Peer-Reviewed Article 招待査読論文

\title{
The Effects of Customization via Starting Solutions on Customer Values:
}

Focusing on the Structure of Customization Values and the Heterogeneity of Customer Design Skills

\section{ソリューション提示型カスタマイゼーションの効果 \\ 一 カスタマイゼーション価值の構造と顧客のデザイン・ \\ スキルの異質性を考慮してー}

Kosaku Morioka*1
東京経済大学 経営学部
森岡 耕作
${ }^{* 1}$ Faculty of Business Administration, Tokyo Keizai University, Japan, morioka@tku.ac.jp

\begin{abstract}
Mass customization (MC) is a product strategy that can meet heterogeneous customer needs. Among various kinds of MC systems, customization via starting solutions (CvSS) has attracted academic attention as a method of reducing configuration costs, and its effectiveness has been examined. However, existing studies examining the effectiveness of CVSS have limitations in two respects; 1) focusing only on limited MC values, and 2) ignoring the heterogeneity of customer design skills. The purposes of this paper are 1) to specify the structure of MC values perceived by customers, and 2) to examine the effects of CvSS based on the structure of MC values. The results of Study 1 show that the MC process value, consisting of enjoyment and process effort, enhances the MC product value, which consists of preference fit and self-expressiveness. The results of Study 2 show that customers with high design skills perceive less enjoyment in the CvSS process than those with lower design skills.
\end{abstract}

Keyword : Process effort, Enjoyment, Preference fit, Self-expressiveness

要約 : 異質な顧客二ーズに対応できる有効な製品戦略であるマス・カスタマイゼーション（MC）の中でも, 顧客の構成負担を 軽減しうるソリューション提示型カスタマイゼーション (CvSS) が注目を集めており, その有効性が吟味されている。しかし ながら，このCvSSに関する既存研究は，第一に，MCについて顧客が知覚する価值のうち限られた種類の価値にしか注目して おらず, 第二に，そのシステムを利用する顧客のデザイン・スキルにおける異質性を考慮していない, という問題を抱えてい る。そこで本論は，第一に，顧客が知覚する MC 価值の構造を特定化し，第二に，その価值構造を前提に，CvSS の効果を吟味 しようと試みた。サーベイ・データを利用して行った分析（分析 1）の結果, 享楽性と過程努力とによって構成される MC 過程 価值が，選好合致亡自己表現性とによって構成される MC 製品価値を高めるということを見出した。そして，実験デー夕を利用 して行った分析（分析 2）の結果，デザイン・スキルの低い顧客より，デザイン・スキルの高い顧客の方が，MC 過程において ソリューションが提示された時に知覚する享楽性が低いということを見出した。

キーワード : 過程努力, 享楽性, 選好合致, 自己表現性

Information : Received 1 March 2020; Accepted 31 March 2020 


\section{I. 導入}

マス・カスタマイゼーション（MC）は, 多様な顧客 ニーズに対応するために，個人化された製品・サービス を提供する製品戦略の 1 つである。これまでに展開され てきた MC研究は, そのような MC が顧客にもたらす種々 の価值（MC 価值）を特定化してきた。具体的には, MC において顧客によって構成された製品を意味する MC 製 品に着目すると, 顧客は自身のニーズや欲求に合致させ て製品を構成できるために，そうして構成された製品は 既製の標準品に比して，高い選好合致を実現したり（e.g., Dellaert \& Stremersch, 2005; Randall, Terwiesch, \& Ulrich, 2007)，高い自己表現性をもたらしたりする（e.g., Kaiser, Schreier, \& Janiszewski, 2017; Merle, Chandon, \& Roux, 2008)。他方, MC における顧客による製品構成過 程を意味する $\mathrm{MC}$ 過程に着目すると，顧客は既に企業に よって構成された標準品とは異なって, 自らその構成に 従事できるために，そこに享楽性を知覚するであろう (e.g., Dellaert \& Dabholkar, 2009; Franke \& Schreier, 2010）。しかしながら，顧客自身が製品構成に従事する ということは, 標準品であれば企業によって負担される ベきコストがその顧客に転嫁されることを意味する。つ まり，MCにおいて顧客は，標準品の選択よりも大きな 過程努力を投じなければならない（e.g., Dellaert \& Stremersch, 2005; Franke \& Schreier, 2010)。

これら多様な MC 価值のうち，ネガティブな価值であ る過程努力について，それを軽減しうる新たな $\mathrm{MC}$ シス テムも開発されている。その1つがソリューション提示 型カスタマイゼーション (customization via starting solutions; CvSS) である（Hildebrand, Häubl, \& Herrmann, 2014）。これは，既にデザインされた製品に修正を加え る $\mathrm{MC}$ システムであり，製品を構成すべき諸属性をまっ さらな状態から顧客が逐次選択する従来型 MC システム （attribute by attribute; AbA）とは，製品構成に先行して ソリューションとしてのデザイン例が顧客に提示される 点で異なっている。そして，この CvSS は，それを利用 する顧客の過程努力を減らしつつ, 同時に高い顧客満足 を実現するという（Hildebrand et al., 2014）。
しかしながら, CvSSの効果を吟味してきた既存研究 (e.g., Hildebrand et al., 2014; Valenzuela, Dhar, \& Zettelmeyer, 2009）は, CvSS が過程努力をいかにして軽 減するかということに焦点を合わせており，そのシステ ムがその他の MC 価值にどのような影響を及ぼすのかと いうことを吟味していない。さらに, 既製品供給とは異 なって，MC は顧客自身が製品構成に従事することので きるシステムであるということと, それを行う顧客のデ ザイン・スキルについて異質性が存在しうるということ (cf., Moreau, Bonney, \& Herd, 2011) を併せて考慮すると, $\mathrm{MC}$ の 1 形態である CvSS の効果は, 必ずしも多様な顧 客にとって一定であるとは言えないであろう。

そこで, 本論は, 上記の問題を解決するために, 第一 に, 顧客が知覚する $\mathrm{MC}$ 価值の構造を検討し, 第二に, それを踏まえた上で, デザイン・スキルにおける顧客の 異質性を考慮することによって CvSS の効果を吟味する。

\section{II. 分析 $1: M C$ 価值の構造}

\section{1. 分析の目的と仮説}

本節は, 顧客が知覚する $\mathrm{MC}$ 価值について, その構造 とそれらの間の関係を経験的に吟味することを目的と する。

既存研究が特定化してきた多様な MC 価值を分類する ために, Holbrook（1999）の価值類型の枠組を援用する。 そうすると, それらの MC 価值は, 表 1 のようにまとめ られる。しかしながら, 大半の既存研究は, それら 4 つ の $\mathrm{MC}$ 価值を包括的に吟味してはいない。例えば, Dellaert and Stremersch（2005）は, MC 価值の功利性, すなわち 過程努力と選好合致にのみ焦点を合わせており, 刘照的 に, Kaiser et al.（2017）は， MC 価值の快楽性，すなわ ち享楽性と自己表現性にのみ焦点を合わせている。他方, Franke and Schreier（2010）は, MC 価值の功利性と快楽 性とを併せて考慮して, 過程努力, 享楽性, 選好合致の 3 つの MC 価值に焦点を合わせているものの, 自己表現 性を考慮していない。さらに, Merle et al.（2008）は, 本論と同様に Holbrook（1999）の価值類型の枠組に基づ いて，包括的に $\mathrm{MC}$ 価值を把握しょうと試みているもの 


\begin{tabular}{|c|c|c|}
\hline & MC 過程価值 & MC 製品価值 \\
\hline $\begin{array}{l}\mathrm{MC} \text { 価值の } \\
\text { 功利性 }\end{array}$ & $\begin{array}{l}\text { 過程努力 (Dellaert \& Stremersch, 2005; Franke \& } \\
\text { Schreier, 2010; Franke, Schreier, \& Kaiser, 2010) }\end{array}$ & $\begin{array}{l}\text { 選好合致 (Dellaert \& Stremersch, 2005; Franke, } \\
\text { Keinz, \& Schreier, 2008; Franke \& Schreier, 2010; } \\
\text { Merle et al., 2008; Randall et al., 2007) }\end{array}$ \\
\hline $\begin{array}{l}\mathrm{MC} \text { 価值の } \\
\text { 快楽性 }\end{array}$ & $\begin{array}{l}\text { 享楽性 (Dellaert \& Dabholkar, 2009; Franke \& Sch- } \\
\text { reier, 2010; Kaiser et al., 2017; Merle et al., 2008) }\end{array}$ & 自己表現性（Kaiser et al., 2017; Merle et al., 2008） \\
\hline
\end{tabular}

の，享楽性の一側面にすぎない創造的達成を享楽性とは 別に考慮してしまっている点，および，それゆえに，過 程努力を捨象している点において，問題を抱えている。

そこで, 既存研究が抱える上記の問題を解消すべく, 本論は, 次のような $\mathrm{MC}$ 価值の構造を想定する。 $\mathrm{MC}$ 過 程価値とは，MCにおける顧客による製品構成過程すな わち MC 過程がもたらす価值である。この価值は功利性 に関連した過程努力と, 快楽性に関連した享楽性とに区 別される。製品構成の過程で投じられた時間と労力に関 する顧客の知覚として定義される過程努力に関して, MC において顧客は，時間と労力を投じて製品を構成する必 要があるため, 過程努力を高く知覚する（Dellaert \& Stremersch, 2005; Franke \& Schreier, 2010)。この種の価 值は, 顧客にとってコストと見なされて, MC 過程価値 に対してネガティブに寄与すると考えられる。また，顧 客自らが製品構成に従事することによって生起するポジ ティブな情緒的反応として定義される享楽性に関して, MC において顧客は, 自らの属性選択によって製品を構 成することに喜びを感じるため，享楽性を高く知覚する (Franke \& Schreier, 2010)。この種の価值は, 顧客にとっ て便益と見なされて，MC 過程価值にポジティブに寄与 すると考えられる。こうして, 過程努力と享楽性とによっ て，MC 過程価值は構成されるであろう。

他方, MC 製品価值とは, カスタマイゼーションの結 果として構成された製品がもたらす価值である。この価 值は, 功利性に関連した選好合致と, 快楽性に関連した 自己表現性とに区別される。構成された製品の特性と顧 客自身の選好との一致度についての主観的評価として定 義される選好合致に関して，顧客は，自らのニーズに基 づいて製品を構成できるために， MC 製品の選好合致を 高く知覚する（Dellaert \& Stremersch, 2005）。また，構
成された製品がどの程度顧客の個性を表現できているの かについての主観的評価として定義される自己表現性に 関して，顧客は，「自ら」が構成した製品であるために， $\mathrm{MC}$ 製品の自己表現性を高く知覚する（Kaiser et al., 2017; Merle et al., 2008)。これら 2 つの価值は, 顧客に とって便益と見なされて, MC 製品価值にポジティブに 寄与すると考えられる。こうして, 選好合致と自己表現 性とによって，MC 製品価值は構成されるであろう。

以上のような $\mathrm{MC}$ 価值の構造を前提にすると, $\mathrm{MC}$ 過 程価值と $\mathrm{MC}$ 製品価值との間には正の因果的関係がある と考えられる。具体的には，顧客は，MC 過程における 構成努力を低く知覚することによって, $\mathrm{MC}$ 製品の選好 合致を高く知覚したり（Hildebrand et al., 2014），かつ／ または, MC 過程における享楽性を高く知覚することに よって, $\mathrm{MC}$ 製品の自己表現性も高く知覚したりするで あろう（Kaiser et al., 2017）。逆に, 顧客は, MC 過程に おける構成努力を高く知覚することによって, $\mathrm{MC}$ 製品 の選好合致を低く知覚したり，かつ／または, $\mathrm{MC}$ 過程 における享楽性を低く知覚することによって, MC 製品 の自己表現性も低く知覚したりするであろう。こうして, 顧客は, $\mathrm{MC}$ 過程価值を高く知覚すると, $\mathrm{MC}$ 製品価值 も高く知覚し, 逆に, MC 過程価值を低く知覚すると, $\mathrm{MC}$ 製品価值も低く知覚すると考えられる。したがって, 以下の仮説を提唱する。

仮説 1：MC 過程価值は $\mathrm{MC}$ 製品価值に正の影響を及ぼ す。

さらに, $\mathrm{MC}$ 製品価值と $\mathrm{MC}$ 製品への満足との間には 正の因果的関係があると考えられる。具体的には, 顧客 は，選好合致を高く知覚したり（Franke et al., 2008），か 
つ／または，自己表現性を高く知覚することによって (Kaiser et al., 2017)，MC 製品に対する満足を高く知覚す るであろう。逆に, 顧客は, 選好合致を低く知覚したり, かつ／または，自己表現性を低く知覚することによって， $\mathrm{MC}$ 製品に対する満足を低く知覚するであろう。こうし て，顧客は，MC 製品価值を高く知覚すると， $\mathrm{MC}$ 製品 に対する満足も高く知覚し, 逆に, MC 製品価值を低く 知覚すると, $\mathrm{MC}$ 製品に対する満足も低く知覚すると考 えられる。したがって，以下の仮説を提唱する。

仮説 $2: \mathrm{MC}$ 製品価值は $\mathrm{MC}$ 製品に対する満足に正の影 響を及ぼす。

\section{2. データ収集}

マクロミル社の調査回答者パネルを利用して, ウェブ 調査を実施した。調查に際して，分析者によって予め指 定された 9 つの対象製品カテゴリ（食品，家具，家電， 化粧品, アパレル品, 服飾雑貨, オートバイ, 自転車, 写真）のいずれかについて，回答者にウェブ上における 直近の MC 製品の購買経験を想起するように求めた。そ の上で，既存研究に依拠して設定された各概念の諸項目
に「非常にそう思う（7 点)」〜「全くそう思わない（1 点)」までの 7 点リカート尺度で回答するよう依頼した。 こうして 916 名からの回答が得られた。

\section{3. 測定}

既存研究から測定項目を引用して, 過程努力 (Franke $\&$ Schreier, 2010), 享楽性 (Franke \& Schreier, 2010; Merle et al., 2008），選好合致（Franke \& Schreier, 2010; Merle et al., 2008），自己表現性（Merle et al., 2008），および MC 製品に対する満足（Hildebrand et al., 2014; Valenzuela et al., 2009）を 7 点リカート尺度で測定した。なお，すべて の項目について, 天井効果と床効果は確認されなかった (表 2)。

各概念に対する測定項目について, Bagozzi and Yi （1988）と Henseler, Ringle, and Sarstedt（2015）に従っ て，信頼性と妥当性を評価すべく確認的因子分析を行っ た（表 3)。その結果, RMSEA が 0.05 であったというこ とから，一次元性に関する信頼性が認められる。また， 収束妥当性について, 各概念の CR が 0.65 0.89, AVE が 0.51〜0.74 であったということから, 項目はそれが測 定しょうとする各概念に首尾よく収束していると判断さ

\begin{tabular}{|c|c|c|}
\hline 概念·項目 & mean & s.d. \\
\hline \multicolumn{3}{|l|}{ 過程努力（Franke \& Schreier, 2010） } \\
\hline その製品をカスタマイズするのは多くの労力のいることだと感じた。 & 3.47 & 1.41 \\
\hline その製品をカスタマイズしているときに疲労を感じた。 & 3.85 & 1.46 \\
\hline その製品のカスタマイズを行うことは時間のかかることだと感じた。 & 3.34 & 1.38 \\
\hline \multicolumn{3}{|l|}{ 享楽性（Franke \& Schreier, 2010; Merle et al., 2008） } \\
\hline その製品のカスタマイズを行うのは楽しい経験だと感じた。 & 3.30 & 1.40 \\
\hline その製品をカスタマイズするのは喜びをもたらす経験であった。 & 3.19 & 1.37 \\
\hline その製品をカスタマイズできるのは面白い経験であった。 & 3.26 & 1.34 \\
\hline \multicolumn{3}{|l|}{ 選好合致（Franke \& Schreier, 2010; Merle et al., 2008） } \\
\hline 自分自身でカスタマイズした製品は，理想の製品に一致するものであった。 & 3.25 & 1.11 \\
\hline 自分自身でカスタマイズした製品は，既製の標準品と比べてよいものであった。 & 3.26 & 1.16 \\
\hline 自分自身でカスタマイズした製品は，自身にとって最もよいものであった。 & 3.05 & 1.19 \\
\hline \multicolumn{3}{|l|}{ 自己表現性（Merle et al., 2008） } \\
\hline 自分自身を表現するような製品を作ることができた。 & 3.54 & 1.29 \\
\hline カスタマイズされたその製品は，あなた自身を反映するものであった。 & 3.63 & 1.27 \\
\hline カスタマイズされたその製品は，まさに私自身かのようであった。 & 4.03 & 1.32 \\
\hline \multicolumn{3}{|l|}{ MC 製品に対する満足（Hildebrand et al., 2014; Valenzuela et al., 2009） } \\
\hline カスタマイズした製品に不満を感じた。(逆転項目) & 3.28 & 1.35 \\
\hline 総じて, カスタマイズした製品に満足できた。 & 3.17 & 1.24 \\
\hline
\end{tabular}


れる。最後に, 弁別妥当性について, 概念間の HTMT 比 が 0.72〜0.84であったということから，対応する項目に よって測定される概念は，それぞれ他の概念と弁別され るものであると判断される。

\section{4. 分析結果と考察}

共分散ベースの構造方程式モデリング（最尤推定）に よって，本論のモデルを推定した（表 4)。それと同時 に，代替モデルとして Merle et al.（2008）のモデルの推 定を行った（表 4）。本論のモデルの AIC と BIC がそれ ぞれ 28,843.15と29,002.21であったのに対して, Merle et al. (2008) のモデルの AIC と BIC はそれぞれ 36,828.81 と 36,992.69 であった。このことから，モデルの複雑さ を考慮しても，本論のモデルは，過程努力を捨象してい るという問題を抱えていた Merle et al.（2008）のモデル に比して，データによく適合していると判断される。

本論のモデルにおける概念間の関係に焦点を合わせる と, 図 1 に要約される結果が得られた。具体的には, MC 過程価值が享楽性と過程努力によって構成される高次因 子であるということ, 同様に, $\mathrm{MC}$ 製品価值が選好合致 と自己表現性によって構成される高次因子であるという ことが，ともに見出された。しかしながら，MC 過程価 值に対する過程努力の因子負荷量は, 正で有意であり
( $\operatorname{std} . \gamma=0.57, z=13.52)$ ，想定とは逆の結果が得られた。

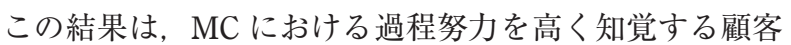
は，製品構成に投じた多くの時間と労力をコストとして ではなく，むしろポジティブな経験として知覚している ということを示唆している。

他方, $\mathrm{MC}$ 過程価值が $\mathrm{MC}$ 製品価值に及ぼす影響を示 すパス係数の標準化推定值は, 正かつ $1 \%$ 水準で統計的 に有意であった $(\operatorname{std} . \gamma=0.88, z=15.98)$ 。この結果は, $\mathrm{MC}$ 過程価值を高く知覚する顧客は, $\mathrm{MC}$ 製品価值も高く知 覚するということを示唆している。したがって，仮説 1 は経験的に支持されたと判断されるであろう。さらに, $\mathrm{MC}$ 製品価值が $\mathrm{MC}$ 製品に対する満足に及ぼす影響を示 すパス係数の標準化推定值は, 正かつ $1 \%$ 水準で統計的 に有意であった（ $\operatorname{std} . \beta=0.81, z=9.14 ） 。 こ の$ 結果は, $\mathrm{MC}$ 製品価值を高く知覚する顧客は, $\mathrm{MC}$ 製品に対する満足 も高く知覚するということを示唆している。したがって, 仮説 2 は経験的に支持されたと判断されるであろう。

以上のことから, MCにおいて享楽性と過程努力によっ て構成される $\mathrm{MC}$ 過程価值を高く知覚する顧客は, 選好 合致と自己表現性によって構成される MC 製品価值を高 く知覚し, 結果として, $\mathrm{MC}$ 製品に対する満足も高く知 覚するという知見が得られた。

\begin{tabular}{lccccccc}
\cline { 2 - 7 } & CR & AVE & $(1)$ & $(2)$ & $(3)$ & $(4)$ & $(5)$ \\
\hline (1) 過程努力 & 0.83 & 0.63 & 0.79 & 0.55 & 0.44 & 0.50 & 0.33 \\
(2) 享楽性 & 0.89 & 0.74 & 0.56 & 0.86 & 0.77 & 0.75 & 0.83 \\
(3) 選好合致 & 0.85 & 0.65 & 0.44 & 0.77 & 0.81 & 0.81 & 0.84 \\
(4) 自己表現性 & 0.86 & 0.67 & 0.50 & 0.76 & 0.81 & 0.82 & 0.69 \\
(5) MC 製品に対する満足 & 0.65 & 0.51 & 0.37 & 0.74 & 0.79 & 0.70 & 0.72 \\
\hline
\end{tabular}

注） CR と AVE を除く行列について，下三角行列は因子間相関係数，対角成分は AVEの平方根，および上三 角行列は HTMT 比をそれぞれ表している。

\section{表 4 MC 価值に関するモデルの比較}

\begin{tabular}{|c|c|c|c|c|c|c|c|}
\hline & & $\chi^{2} /$ d.f. & RMSEA & AGFI & CFI & AIC & $\mathrm{BIC}$ \\
\hline 本論のモデル & & 4.25 & 0.06 & 0.94 & 0.97 & $28,843.15$ & $29,002.21$ \\
\hline Merle et al. (2008) & のモデル & 6.47 & 0.08 & 0.89 & 0.94 & $36,828.81$ & $36,992.69$ \\
\hline
\end{tabular}




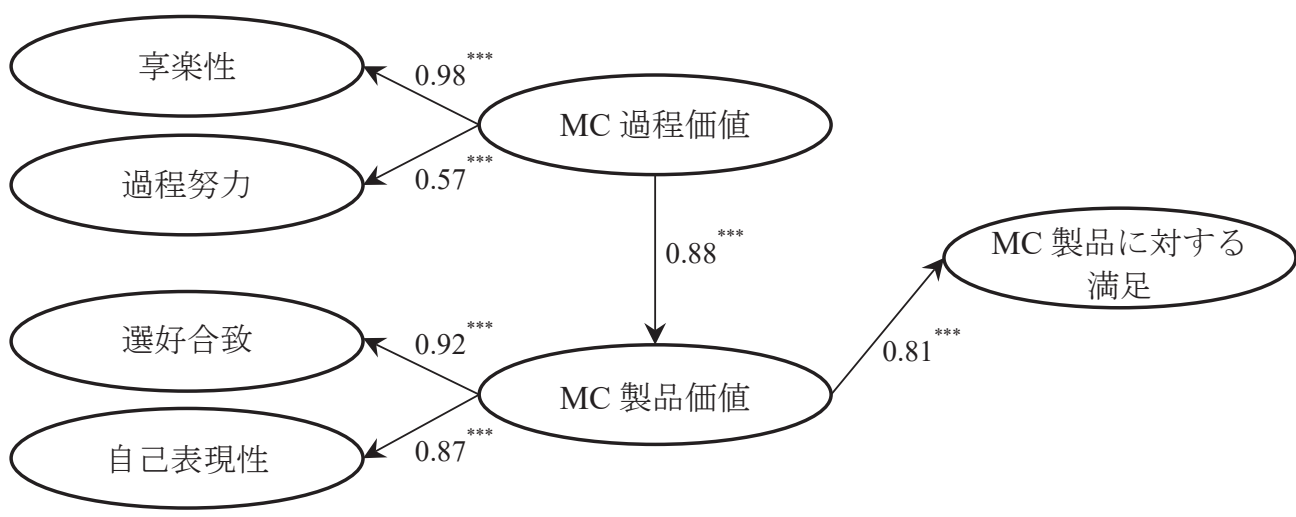

注）***は $1 \%$ 水準で統計的に有意であるを示す。

\section{III. 分析 2：CvSS の効果}

\section{1. 分析の目的と仮説}

本節は，前節において得られた知見を踏まえて，CvSS が MC 価值に及ぼす影響を経験的に吟味することを目的 とする。

CVSS は, トップダウン型情報処理を促すシステムで あるという（Hildebrand et al., 2014）。具体的には, CvSS は，企業が最初に既製品を提示することによって顧客の ニーズを喚起させる一方，そうしてニーズを認識できる ようになった彼らに，最初に提示された製品の修正のみ を求めるシステムである。このような特徵を持つ CvSS は，顧客の情報処理が容易になされる程度として定義さ れる情報処理流暢性を向上させるという（de Bellis， Hildebrand, Ito, Herrmann, \& Schmitt, 2019)。そうする と，顧客は，MC 過程において製品構成の困難性を低く 知覚し (Hildebrand et al., 2014)，それゆえに，多くの努 力を投じることなく製品構成を行うことができる。つま り，CvSSに扔いて顧客は，過程努力を低く知覚すると 考えられる。他方，ある活動において情報処理流暢性の 高い顧客は，その活動に没頭でき，それゅえ，そこに高 い享楽性を知覚するという（Im＆ Ha, 2011）。この知見 を援用すると，CvSSに打いても顧客は，享楽性を高く 知覚すると考えられる。
他方, AbA は, ボトムアップ型情報処理を顧客に求め るシステムであるという（Hildebrand et al., 2014）。具体 的には，AbA は，自らのニーズ把握とそれを充足するた めの製品構成のいずれをも顧客に求めるシステムである。 このような特徵を持つ AbA は, CvSS とは対照的に, MC 過程における顧客の情報処理を非流暢にしてしまうとい う（de Bellis et al., 2019）。そうすると，顧客は， MC 過 程に扔いて製品構成の困難性を高く知覚し（Hildebrand et al., 2014)，それゆえに，多くの努力を投じて製品構成 を行わなければならない。つまり, AbA において顧客 は, 過程努力を高く知覚すると考えられる。他方, 先述 のとおり, ある活動において情報処理流暢性の低い顧客 は，その活動に没頭できないがゆえに，そこに低い享楽 性しか知覚しないという（Im\& Ha, 2011）。この知見を 援用すると, $\mathrm{AbA}$ に扔いても顧客は, 享楽性を低く知覚 すると考えられる。

ここで，MC システムを利用する顧客のデザイン・ス キルにおける異質性を考慮する。デザイン・スキルとは 構成すべき製品を適切に構成することのできる程度を意 味し，そこには，問題定義と問題解決の 2 側面から捉え られる創造性が含まれる（Moreau \& Dahl, 2009）。つま り， MC システムを利用する際に，デザイン・スキルの 高い顧客は，いかなる製品を構成すべきかを自ら認識し ており，さらにそれに向けて確実に製品を構成できると いうことである。それにもかかわらず，デザイン・スキ 
ルの高い顧客が CvSS において製品構成を行うとなる と, 彼らは製品構成による問題解決だけでなく，そもそ も提示された既定の問題を定義し直し，さらに製品構成 上の修正を施す必要が生じるであろう。その結果として, Hildebrand et al.（2014）の想定とは逆に，デザイン・ス キルの高い顧客は，CVSS によって情報処理流暢性が低 下するために，高い過程努力を知覚すると考えられる。 同様に，彼らは，CvSSによって情報処理流暢性が低下 するために，製品構成過程に没頭できず，そこに低い享 楽性しか知覚しえないであろう。

対照的に，デザイン・スキルの低い顧客が CvSS にお いて製品構成を行うとなると，製品提示によって自らの ニーズを認識できるようになった彼らは，提示された製 品に修正を施すだけでよい。その結果として, デザイン・ スキルの低い顧客は，CvSSによって情報処理流暢性が 向上するために，過程努力を低く知覚すると考えられる。 同様に，彼らは，CvSSによって情報处理流暢性が向上 するために，製品構成過程に没頭でき，そこに高い享楽 性を知覚するであろう。したがって，以下の仮説を提唱 する。

仮説 3：CVSS を利用する顧客が知覚する MC 過程価值 は，顧客のデザイン・スキルによって異なる。 仮説 3a：デザイン・スキルの高い顧客は，デザイン・ スキルの低い顧客に比して，CvSS を利用す るときに過程努力を高く知覚する。

仮説 $3 \mathrm{~b}$ ：デザイン・スキルの高い顧客は, デザイン・ スキルの低い顧客に比して，CvSS を利用す るときに享楽性を低く知覚する。

上記のとおり， MC システムを利用する顧客のデザイ ン・スキルの高低によって，CvSS における MC 過程価 值に差異が生じる。さらに，前節の分析 1 のとおり，MC 過程価值は MC 製品価值に正の影響を及ほす。これらの ことを踏まえると，CvSSにおいて製品構成を行う場合， デザイン・スキルの高い顧客は過程努力を高く知覚した り，かつ／または，享楽性を低く知覚したりすることに よって，MC 過程価值を低く知覚する一方，デザイン・ スキルの低い顧客は過程努力を低く知覚したり，かつ／
または，享楽性を高く知覚したりすることによって，MC 過程価值を高く知覚するであろう。さらに，そうして生 じる $\mathrm{MC}$ 過程価值の差異は, $\mathrm{MC}$ 製品価值の差異をも生 ビさせる。具体的には，デザイン・スキルの高い顧客は， $\mathrm{MC}$ 過程価値を低く知覚することによって, MC 製品価 值も低く知覚する一方で, デザイン・スキルの低い顧客 は，MC 過程価値を高く知覚することによって，MC 製 品価值も高く知覚するであろう。

CvSS における状況とは対照的に, AbAに押いて製品 構成を行う場合，デザイン・スキルの高い顧客は過程努 力を低く知覚したり，かつ／または，享楽性を高く知覚 したりすることによって，MC 過程価值を高く知覚する 一方，デザイン・スキルの低い顧客は過程努力を高く知 覚したり，かつ／または，享楽性を低く知覚したりする ことによって，MC 過程価值を低く知覚するであろう。 さらに，先述のとおり，そうして生じる $\mathrm{MC}$ 過程価值の 差異は，MC 製品価值の差異をも生じさせる。具体的に は，デザイン・スキルの高い顧客は，MC 過程価値を高 く知覚することによって，MC 製品価值も高く知覚する 一方で, デザイン・スキルの低い顧客は, $\mathrm{MC}$ 過程価值 を低く知覚することによって，MC製品価值も低く知覚 するであろう。

このように, MC システムが CvSS であるか $\mathrm{AbA}$ であ るかの差異は, 顧客の知覚する $\mathrm{MC}$ 過程価値の差異を介 して，MC 製品価值に影響すると考えられる。したがっ て，以下の仮説を提唱する。

仮説 4：CvSS は, MC 過程価値を介して, MC 製品価値 に影響を及ぼす。

\section{2. 実験と手続き}

仮説の経験的テストに利用するデー夕を収集するため に, 実験室実験を行った。実験参加者は, 36 名（男性 20 名・女性 16 名）の都内大学生であり, 平均年齢 21.36 歳であった。

実験に際して, 参加者がカスタマイズする製品として, Moreau and Herd（2010）に做って, 携帯電話ケースを選 定した。また，カスタマイゼーションに際して，実際に 存在するウェブ・プラットフォームを利用した。 
実験は， 1 要因（CvSS／AbA）が操作された 2 つのグ ループのいずれかに無作為に割り当てられた各参加者が, 携帯電話ケースのカスタマイゼーションを実行する被験 者間計画であった。参加者に対して，まず，デザイン・ スキル（Moreau et al., 2011）を測定するための項目に 7 点リカート尺度で回答するように指示し（表 5), その後 に携帯電話ケースのカスタマイズを行うウェブ・プラッ トフォームの基本的操作を説明した。そして, CvSSグ ループの参加者には，既にデザインされた携帯電話ケー スを提示し，それに修正を加えてカスタマイズするよう 求め, 他方, $\mathrm{AbA}$ グループの参加者には, まっさらな状 態の基本ケースを提示し, カスタマイズするよう求めた。 こうして，それぞれの参加者は，15 分の制限時間の中で 携帯電話ケースを自由にカスタマイズした。最後に，カ スタマイズ終了後すぐに，過程努力（Franke \& Schreier, 2010), 享楽性 (Franke \& Schreier, 2010; Merle et al., 2008），選好合致（Franke \& Schreier, 2010; Merle et al., 2008），および自己表現性（Merle et al., 2008）に関する 諸項目に, 7 点リカート尺度で回答するよう参加者に求 めた（表 5)。

\section{3. 分析結果と考察}

仮説 3 を経験的にテストするために, CvSS ダミー, デザイン・スキル，および CvSS ダミーとデザイン・ス キルの交互作用項を独立変数として，他方，過程努力と 享楽性をそれぞれ従属変数として設定した 2 つ回帰モ デルをOLSによって推定した（表 6)。また，仮説 4 を 経験的にテストするために, CvSS ダミー, デザイン・ スキル，および CvSS ダミーとデザイン・スキルの交互 作用項に加えて, $\mathrm{MC}$ 過程価值を構成する過程努力と享 楽性を独立変数として，他方，選好合致と自己表現性を それぞれ従属変数として設定した 2 つの回帰モデルを OLSによって推定した（表 6)。なお, すべての回帰モデ ルにおける CvSS ダミーとデザイン・スキルの交互作用 項は，デザイン・スキルに-0.5（AbA）か $0.5(\mathrm{CvSS})$ のいずれかを乗じて作成された。

まず，過程努力を従属変数とするモデルにおいて， CvSS ダミーとデザイン・スキルの交互作用項は有意な

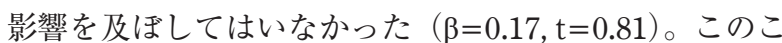
とは，利用される $\mathrm{MC}$ システムが $\mathrm{CvSS}$ と AbA のいずれ の場合であっても, 顧客のデザイン・スキルの高低によっ

\begin{tabular}{|c|c|c|}
\hline 概念・項目 & mean & s.d. \\
\hline \multicolumn{3}{|l|}{ 過程努力（Franke \& Schreier, 2010） } \\
\hline その製品をカスタマイズするのは多くの労力のいることだと感じた。 & 4.24 & 1.49 \\
\hline その製品をカスタマイズしているときに疲労を感じた。 & 3.26 & 1.47 \\
\hline その製品のカスタマイズを行うことは時間のかかることだと感じた。 & 4.54 & 1.79 \\
\hline \multicolumn{3}{|l|}{ 享楽性（Franke \& Schreier, 2010; Merle et al., 2008) } \\
\hline その製品のカスタマイズを行うのは楽しい経験だと感じた。 & 5.15 & 1.66 \\
\hline その製品をカスタマイズするのは喜びをもたらす経験であった。 & 4.72 & 1.42 \\
\hline その製品をカスタマイズできるのは面白い経験であった。 & 5.02 & 1.41 \\
\hline \multicolumn{3}{|l|}{ 選好合致（Franke \& Schreier, 2010; Merle et al., 2008） } \\
\hline 自分自身でカスタマイズした製品は，理想の製品に一致するものであった。 & 3.59 & 1.41 \\
\hline 自分自身でカスタマイズした製品は, 既製の標準品と比べてよいものであった。 & 3.35 & 1.51 \\
\hline 自分自身でカスタマイズした製品は，自身にとって最もよいものであった。 & 3.48 & 1.57 \\
\hline \multicolumn{3}{|l|}{ 自己表現性（Merle et al., 2008） } \\
\hline 自分自身を表現するような製品を作ることができた。 & 4.26 & 1.65 \\
\hline カスタマイズされたその製品は，あなた自身を反映するものであった。 & 3.93 & 1.73 \\
\hline カスタマイズされたその製品は，まさに私自身かのようであった。 & 3.22 & 1.58 \\
\hline \multicolumn{3}{|l|}{ デザイン・スキル（Moreau et al., 2011） } \\
\hline 自分自身がその製品カテゴリの製品をデザインするなら，良いデザイナーになれる。 & 3.30 & 1.87 \\
\hline その製品カテゴリの製品をデザインするために必要なスキルをもっている。 & 2.89 & 1.96 \\
\hline クリエイティビティ (創造性) は, 自身のアイデンティティの一部である。 & 4.57 & 1.63 \\
\hline 友人がその製品カテゴリの製品デザインを友人の誰かに頼むならば，あなたが選ばれるだろう。 & 2.74 & 1.73 \\
\hline
\end{tabular}




\begin{tabular}{lcccc} 
& $\begin{array}{c}\text { 従属変数 : } \\
\text { 過程努力 }\end{array}$ & $\begin{array}{c}\text { 従属変数 : } \\
\text { 享楽性 }\end{array}$ & $\begin{array}{c}\text { 従属変数 : } \\
\text { 選好合致 }\end{array}$ & $\begin{array}{c}\text { 従属変数 : } \\
\text { 自己表現性 }\end{array}$ \\
\cline { 2 - 5 } & $\beta(\mathrm{t})$ & $\beta(\mathrm{t})$ & $\beta(\mathrm{t})$ & $\beta(\mathrm{t})$ \\
\hline CvSS ダミー & $-0.44(-0.52)$ & $1.37(1.44)$ & $-0.31(-0.31)$ & $1.04(0.88)$ \\
デザイン・スキル & $-0.05(-0.52)$ & $0.11(0.96)$ & $0.48\left(2.46^{* *}\right)$ & $0.43(1.85)$ \\
過程努力 & - & - & $0.41\left(2.04^{* *}\right)$ & $-0.07(-0.27)$ \\
享楽性 & - & - & $0.32(1.80)$ & $0.48\left(2.26^{* *}\right)$ \\
CvSS ダミー×デザイン・スキル & $0.17(0.81)$ & $-0.59\left(-2.51^{* *}\right)$ & $0.01(0.03)$ & $-0.29(-0.95)$ \\
定数項 & $0.41(0.67)$ & $-1.07(-1.54)$ & $-1.08(-1.06)$ & $0.42(0.34)$ \\
\hline サンプル・サイズ & 36 & 36 & 36 & 36 \\
決定係数 & 0.06 & 0.43 & 0.56 & 0.38 \\
F 值 (自由度) & 0.66 & $8.07^{* * *}$ & $7.75^{* * *}$ & $3.66^{* *}$ \\
\hline
\end{tabular}

注）***は $1 \%$ 水準，**は $5 \%$ 水準でそれぞれ統計的に有意であることを示す。

て，過程努力に差異は生じないということを示唆してい る。この結果から，仮説 $3 \mathrm{a}$ は経験的に支持されなかった と判断される。

次に, 享楽性を従属変数とするモデルにおいて, CvSS ダミーとデザイン・スキルの交互作用項は有意な負の影 響を及ぼしていた（ $\beta=-0.59, \mathrm{t}=-2.51)$ 。すなわ $\mathrm{CvSS}$ の場合，デザイン・スキルの高い顧客は，そうでない顧 客と比べて，享楽性を低く知覚するということを示唆し ている。この結果から，仮説 $3 \mathrm{~b}$ は経験的に支持されたと 判断される。

仮説 4 に関して，まず，選好合致を従属変数とするモ デルにおいて, $\operatorname{CvSS} の$ 主効果 $(\beta=-0.31, \mathrm{t}=-0.31)$ と デザイン・スキルとの交互作用効果 $(\beta=0.01, \mathrm{t}=0.03)$ はいずれも有意ではなかったものの，過程努力が選好合 致に有意な正の影響を及ぼしていた（ $\beta=0.41, \mathrm{t}=2.04)$ 。 しかしながら，先述のとおり，そもそも過程努力を従属 変数とするモデルにおいて, CvSS の効果は見出されて なかった。したがって，過程努力が， CvSS と選好合致 との間の関係を媒介しているとは判断しえない。

次に, 自己表現性を従属変数とするモデルにおいて, $\operatorname{CvSS}$ の主効果（ $\beta=1.04, \mathrm{t}=0.88 ）$ とデザイン・スキルと の交互作用効果 $(\beta=-0.29, \mathrm{t}=-0.95)$ はいずれも有意で はなかったものの，享楽性が自己表現性に有意な正の影 響を及ぼしていた（ $\beta=0.48, t=2.26 ）$ 。関連して，先述の とおり，享楽性を従属変数とするモデルにおいて, CvSS
ダミーとデザイン・スキルの交互作用項は享楽性に有意 な負の影響を及ぼすということが見出されている。これ らの結果は, 享楽性が CvSS と自己表現性との間の関係 を媒介しているということを示唆している。そこで，追 加的に媒介分析によって享楽性の媒介効果を検討したと ころ（ブートストラップ法／リサンプリング数 2,000), CvSS ダミーとデザイン・スキルの交互作用項は享楽性 を媒介して, 自己表現性に有意な負の影響を及ぼしてい

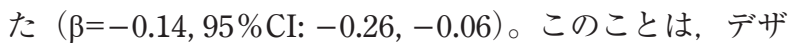
イン・スキルの高い顧客が CvSS において製品構成を行 う場合, MC 過程における享楽性を低く知覚し, 結果と して, 構成された製品の自己表現性も低く知覚するとい うことを示唆している。したがって， MC 過程価值の一 種である享楽性は，CvSS が MC 製品価值の一種である 自己表現性に及ぼす影響を媒介していると判断される。 そして，このことと，過程努力が CvSS と選好合致との 間の関係を媒介はいなかったということとを併せて考慮 すると, 仮説 2 は部分的にのみ支持されたと考えられる。 前段までの分析結果は図 2 に示されるように総合さ れ，同図のとおり，デザイン・スキルの高い顧客が CvSS を利用すると, 必ずしも過程努力を高く知覚するわけで はないものの, 一方, 享楽性を低く知覚し, それゆえ, 構成された製品の自己表現性を低く知覚するという知見 が得られた。 


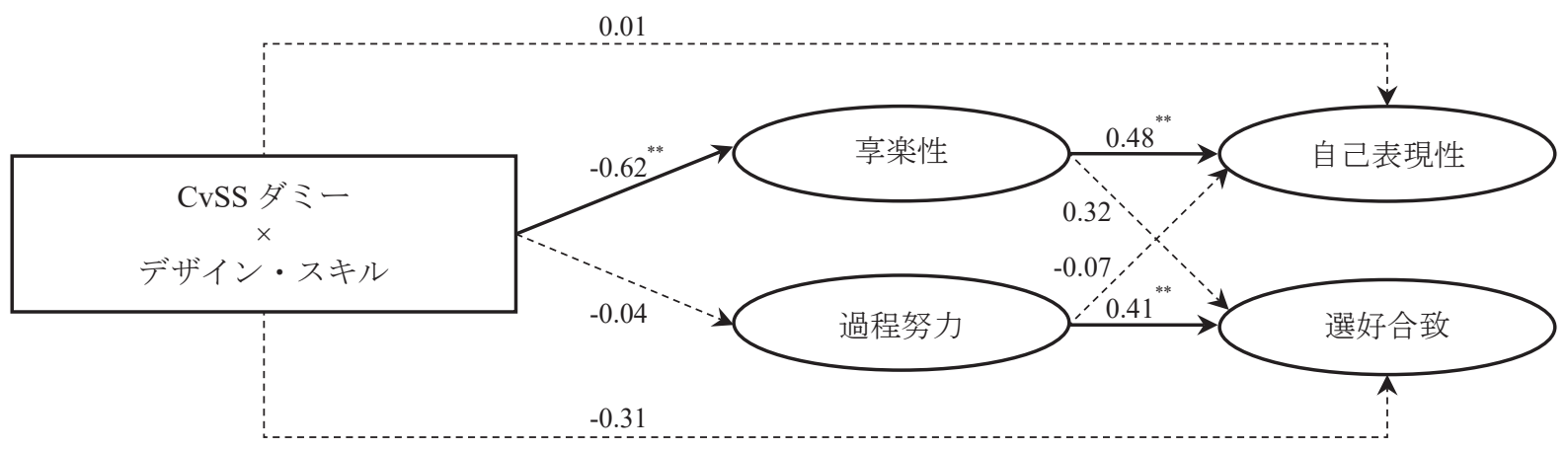

注）**は $5 \%$ 水準で統計的に有意であることを示す。また，破線のパスは，推定值が $5 \%$ 水準で統計的に非有意であることを示す。

\section{IV. 結論}

\section{1. 学術的含意}

本論は，CvSSに関する既存研究が，限られた MC 価 值にしか着目してこなかったことを問題視し，まず，MC 価值を Holbrook（1999）の枠組に基づいて整序すること によって包括的に吟味することを試みた。その過程にお いて，それまでの既存研究によって特定化されてきた過 程努力を捨象しているという Merle et al. (2008) の問題 を解消した。そして，過程価值と享楽性とによって構成 される MC 過程価值が，選好合致と自己表現性とによっ て構成される $\mathrm{MC}$ 製品価值を介して， $\mathrm{MC}$ 製品満足に帰 着するということを見出した。その上で, 顧客のデザイ ン・スキルの異質性を考慮しないままに，過程努力にの み焦点を合わせて, CvSSによるその軽減効果を主張し てきた既存研究とは対照的に, 本論は, 顧客のデザイン・ スキルの異質性を考慮して, CvSS が MC 過程価值を構 成する 2 つ価值に及ぼす影響を吟味した。その結果, 享楽性に対する CvSSの有意な影響が見出された一方, 過程努力に対する CvSS の有意な影響は見出されなかっ た。このことは, 既存研究において主張されてきた CvSS と過程努力との間の負の関係が, 顧客のデザイン・スキ ルの異質性を考慮してこなかったということに起因して 生起したにすぎないという可能性を含意している。

\section{2. 実務的含意}

$\mathrm{MC}$ は多様な顧客ニーズに対応しうるシステムであり， したがって，多くの顧客を獲得しようとする企業が，積 極的にそれを採用しようとするであろう。しかしながら， 顧客が互いに異なるニーズだけでなく，それぞれ異なる デザイン・スキルを有していると, $\mathrm{MC}$ を展開する企業 は, $\mathrm{AbA}$ か $\mathrm{CvSS}$ のいずれかの MC システムしか用意し ていなければ，彼らすべてを満足させることはできない であろう。具体的には, AbA はデザイン・スキルの高い 顧客を満足させる一方, デザイン・スキルの低い顧客の 不満足を生じさせ，逆に， CvSS はデザイン・スキルの 低い顧客を満足させる一方, デザイン・スキルの高い顧 客の不満足を生じさせるであろう。したがって，MCに よって高い顧客満足を獲得するために, 企業は, 高いデ ザイン・スキルを有する顧客に対応して AbA を，他方， 低いデザイン・スキルしか持たない顧客に対応して CvSS を，それぞれ用意することが有効であると考えられる。

\section{3. 本論の限界と今後の課題}

本論において得られた知見は, 次の点に関して, その 一般化可能性が限られる。第一に, 仮説とは逆に, 過程 努力と $\mathrm{MC}$ 過程価值との間にポジティブな関係が見出さ れたことについて，その原因は，本論の調査が日本にお いて実施されたということにあるのかもしれない。Park, Ono, and Endo（2005）は，米国における顧客デー夕を利 用して， MC 過程における複雑性と $\mathrm{MC}$ 製品への態度と 
の間に負の関係を見出しているのに対して，日本におけ る顧客データを利用して，両者の間に正の関係を見出し ている。これらの結果を踏まえると, 調査を実施する地 域を変更してもなお，本論と同様の知見が得られるとは 限らない。第二に, 既存研究に倣って, 本論の実験にお いて参加者に携帯電話ケースのカスタマイゼーションを 課したことについて，それに一定の妥当性が認められる かもしれないが，異なる製品を対象として同様の実験を 実施したときに，本論と同様の知見が得られるとは限ら ない。第三に, 携帯電話ケースのカスタマイゼーション を課す実験の CvSS において最初に提示されるデザイン について，それが本論の実験において提示されたものと は異なるとき，本論と同様の知見が得られるとは限らな い。したがって，これらの限界を克服するための継続的 な取り組みが必要であろう。

他方，本論の知見を拡大するために，次のような課題 を挙げることができる。第一は，新たな MC システムを 想定して分析することである。例えば，Ono, Matsuura， Endo, and Nakagawa（2016）は，製品構成過程の開始時 点でしか顧客への製品提示をしていないという CvSSの 限界を指摘して，新たに，製品構成過程の中間時点でも 顧客への製品提示をする MC システム（customization via waypoint solutions; CvWS）を提唱している。この新たな $\mathrm{MC}$ システムを考慮すると, 高いデザイン・スキルを有 する顧客にとって CvWS において随時なされる製品提示 は, CvSS と比べて, 情報処理を非流暢にし, 享楽性を 低下させる一方，デザイン・スキルの低い顧客にとって CvWS における同様の製品提示は，情報処理を流暢にし， 享楽性を向上させると考えられる。加えて，第二は，MC 製品のパーソナリティと顧客自身のパーソナリティとの 類似性を考慮して分析することである。例えば，Ono （2019）は顧客のパーソナリティと MC 製品のパーソナ リティとの類似性がその製品への評価を規定しうるとい うことを示唆している。このことを踏まえると, $\mathrm{AbA}$, CvSS，およびCvWS における享楽性の差異は，それぞれ の状況で構成される製品の自己表現性の差異を生じさせ るだけでなく, 製品構成を行う顧客自身のパーソナリティ によって, $\mathrm{MC}$ 製品への評価の差異をも生じさせると考 えられる。このように，本論は，いくつかの限界を抱え
つつも，今後の研究展開を期しうると言えるであろう。

\section{謝辞}

本論の執筆段階においてご助言くださった小野晃典先 生（慶應義塾大学）に感謝申し上げます。また, レビュ ワーにも併せて感謝申し上げます。

\section{References}

Bagozzi, R. P., \& Yi, Y. (1988). On the evaluation of structural equation models. Journal of the Academy of Marketing Science, 16(1), 74-94.

de Bellis, E., Hildebrand, C., Ito, K., Herrmann, A., \& Schmitt, B. (2019). Personalizing the customization experience: A matching theory of mass customization interfaces and cultural information processing. Journal of Marketing Research, 56(6), 1050-1065.

Dellaert, B. G., \& Dabholkar, P. A. (2009). Increasing the attractiveness of mass customization: The role of complementary on-line services and range of options. International Journal of Electronic Commerce, 13(3), 43-70.

Dellaert, B. G., \& Stremersch, S. (2005). Marketing masscustomized products: Striking a balance between utility and complexity. Journal of Marketing Research, 42(2), 219-227.

Franke, N., Keinz, P., \& Schreier, M. (2008). Complementing mass customization toolkits with user communities: How peer input improves customer self-design. Journal of Product Innovation Management, 25(6), 546-559.

Franke, N., \& Schreier, M. (2010). Why customers value selfdesigned products: The importance of process effort and enjoyment. Journal of Product Innovation Management, 27(7), 1020-1031.

Franke, N., Schreier, M., \& Kaiser, U. (2010). The "I designed it myself" effect in mass customization. Management Science, 56(1), 125-140.

Henseler, J., Ringle, C. M., \& Sarstedt, M. (2015). A new criterion for assessing discriminant validity in variance-based structural equation modeling. Journal of the Academy of Marketing Science, 43(1), 115-135.

Hildebrand, C., Häubl, G., \& Herrmann, A. (2014). Product customization via starting solutions. Journal of Marketing Research, 51(6), 707-725.

Holbrook, M. B. (1999). Introduction to consumer value. In M. B. Holbrook (ed.). A framework for analysis and research (pp. 128). London: Routledge.

Im, H., \& Ha, Y. (2011). The effect of perceptual fluency and enduring involvement on situational involvement in an online apparel shopping context. Journal of Fashion Marketing and Management, 15(3), 345-362.

Kaiser, U., Schreier, M., \& Janiszewski, C. (2017). The selfexpressive customization of a product can improve performance. Journal of Marketing Research, 54(5), 816-831.

Merle, A., Chandon, J. L., \& Roux, E. (2008). Understanding the 
perceived value of mass customization: The distinction between product value and experiential value of co-design. Recherche et Applications en Marketing (English Edition), 23(3), 27-50.

Moreau, C. P., Bonney, L., \& Herd, K. B. (2011). It's the thought (and the effort) that counts: How customizing for others differs from customizing for oneself. Journal of Marketing, 75(5), 120-133.

Moreau, C. P., \& Dahl, D. W. (2009). Constraints and consumer creativity. In A. B. Markman, \& K. L. Wood (eds.). Tools for innovation: The science behind the practical methods that drive new ideas (pp. 104-127). New York: Oxford University Press.

Moreau, C. P., \& Herd, K. B. (2010). To each his own? How comparisons with others influence consumers' evaluations of their self-designed products. Journal of Consumer Research, 36(5), 806-819.

Ono, A. (2019). Various consumer needs for "facial" product designs: Exploring new customization systems for anthropomorphized products. Japan Marketing Journal, 38(4), 6-19. (小野晃典（2019）。「製品の顔」のデザインに対す るニーズ多様性」『マーケティングジャーナル』38(4), 619) (In Japanese with English abstract)

Ono, A., Matsuura, K., Endo, S., \& Nakagawa, Y. (2016). Exploring the customization decision support system using waypoint solutions. Asia Marketing Journal, 18(1), 23-35.

Park, J., Ono, A., \& Endo, S. (2005). Consumers' intention to purchase e-customized products: Comparison of USA and Japan. International Journal of Business Research, 2(1), 21-35.

Randall, T., Terwiesch, C., \& Ulrich, K. T. (2007). User design of customized products. Marketing Science, 26(2), 268-280.

Valenzuela, A., Dhar, R., \& Zettelmeyer, F. (2009). Contingent response to self-customization procedures: Implications for decision satisfaction and choice. Journal of Marketing Research, 46(6), 754-763.

\section{森岡 耕作（もりおかこうさく）}

東京経済大学経営学部准教授。2005 年慶應義塾大学商学部 卒業。2007 年同大学院商学研究科修士課程修了, 2011 年同 大学院商学研究科博士課程単位取得退学。博士 (商学)。東 京経済大学経営学部専任講師を経て 2014 年より現職。 